\title{
RANCANG BANGUN DAN UJI KINERJA DRIFTER BUOY
}

\author{
(DESIGN AND PERFORMANCE TEST OF DRIFTER BUOY)
}

\author{
Muhammad Iqbal ${ }^{1,2}$, Indra Jaya ${ }^{3}$, dan Mulia Purba \\ Bagian Akustik dan Instrumentasi Kelautan \\ Departemen Ilmu dan Teknologi Kelautan-IPB
}

\begin{abstract}
The modern drifter buoy is a bigh-tech version of the "message in a bottle". It consists of a surface buoy and a subsurface drogue, attached by a long, thin tether. The buoy measures temperature and other sea/ air properties, and has a transmitter to send the data to passing satellites. Drifters buoy for oceanographic research in the field had long been developed, but the design and construction of this instrument is still on going process. The major goal of the drifter intended by the designers of the drifter are cheap, lightweight and stable on several conditions. This study attempted to produce a drifter system capable of measuring position, speed and direction of surface current using a microcontroller, GPS and GSM technology as the data transmitter and receiver. There are 3 main parts of the drifter. They are the electronic systems, software and vehicles. Electronic systems are built from the microcontroller ATmega32, storage SD / MMC cards, transmission using GSM modem, GPS as a sensor position and velocity, and DALLAS DS18B20 as temperature sensors. The software is divided into 2 parts: software that is embedded into vebicle and software to control and receiving data in ground segment. Vebicle is divided into 2 main parts, first is float to house electronics system and drogue to maintain a position of drifter from the influence of surface wind. GPS used has a precision of 10 $m$, therefore the determination of position requires a certain time interval, this interval is very dependent on the speed of surface currents in the area. The results of performance test systems in the field showed that the design is able to record 95\% -99\% of the data successfully at 64 bps transfer speed. Field trial results also showed 85\% and 93\% successful data transmission using the GSM network with the power used in these systems totaling approximately 541-544 $\mathrm{mW}$. The value of drag area ratio is 53.38, greater than 40 indicates that the drifter is produced has a pretty good ability to follow the movement of the water.
\end{abstract}

Keywords : buoy, drifter, oceanographic, GPS, microcontroller, sensor

\begin{abstract}
ABSTRAK
Penggunaan drifter untuk penelitian di bidang oseanografi telah cukup lama dilakukan, namun perancangan, dan pengembangan dari instrumen ini masih terus dilakukan. Rancangan yang murah, ringan dan stabil merupakan beberapa syarat yang dituju oleh para perancang drifter. Di Indonesia penggunaan drifter sebagai alat penelitian oseanografi masih jarang dilakukan dan drifter yang dilepas oleh ARGOS pun hampir tidak ada yang memasuki perairan Indonesia, sehingga penelitian dan analisis data berbasis data drifter inipun masih jarang dilakukan di Indonesia. Ohlman, (2007) mengembangkan drifter yang dirancang untuk perairan pesisir. Beberapa syarat yang ditemukan yaitu drifter pesisir harus memiliki resolusi spasial beberapa meter dan sampel posisi dilakukan setiap beberapa menit. Pengukuran near-real-time data telemetri diperlukan sehingga drifter dapat dilacak dan dipulihkan. Dalam makalah ini diuraikan hasil desain dan konstruksi sistem drifter, serta hasil ujicoba lapang. Diharapkan dari data pengamatan drifter dapat dikembangkan lebih lanjut drifter yang handal dan berkualitas.
\end{abstract}

Kata-kata kunci: pelampung, buoy, oseanografi, GPS, mikrokontroler, sensor

\section{PENDAHULUAN}

Penggunaan drifter untuk penelitian di bidang oseanografi telah cukup lama dilakukan, namun perancangan, dan pengembangan dari instrumen ini masih terus dilakukan. Rancangan yang murah, ringan dan stabil merupakan beberapa syarat yang dituju oleh para perancang drifter. Di Indonesia penggunaan drifter sebagai alat peneliti- an oseanografi masih jarang dilakukan dan drifter yang dilepas oleh ARGOS pun hampir tidak ada yang memasuki perairan Indonesia, sehingga penelitian dan analisis data berbasis data drifter inipun masih jarang dilakukan di Indonesia. Ohlman, (2007) mengembangkan drifter yang dirancang untuk perairan pesisir. Beberapa syarat yang ditemukan yaitu drifter pesisir harus memiliki resolusi spasial beberapa meter

\footnotetext{
${ }^{1}$ Corresponding author

${ }^{2}$ Staf Laboratorium Akustik dan Instrumentasi Kelautan FPIK- IPB

${ }^{3}$ Staf Pengajar Departemen Ilmu dan Teknologi Kelautan FPIK-IPB
} 
dan sampel posisi dilakukan setiap beberapa menit. Pengukuran near-realtime data telemetri diperlukan sehingga drifter dapat dilacak dan dipulihkan. Dalam makalah ini diuraikan hasil desain dan konstruksi sistem drifter, serta hasilujicoba lapang. Diharapkan dari data pengamatan drifter dapat dikembangkan lebih lanjut drifter yang handal dan berkualitas.

\section{BAHAN DAN METODE PENELITIAN}

Perancangan dan pembuatan sistem serta analisis data pada penelitian ini dilaksanakan dari Februari hingga Agustus 2010 di Laboratorium Instrumentasi dan Telemetri Kelautan Bagian Akustik dan Instrumentasi Kelautan Departemen Ilmu dan Teknologi Kelautan, Fakultas Perikanan dan Ilmu Kelautan, Institut Pertanian Bogor. Sedangkan uji coba lapang dilakukan di teluk Pelabuhan Ratu Propinsi Jawa Barat, dilaksanakan pada tanggal 28 dan 30 Agustus 2010.

Penelitian ini terdiri atas beberapa tahapan sebagai berikut:

1. Tahap Perancangan dan Perakitan Sistem

- Rancang Bangun sistem elektronika: sistem elektronika ini terdiri atas GPS dan modem GSM dengan mikrokontroler sebagai pengendali kerja dilengkapi dengan sistem penyimpanan data serta sensor suhu. Pada perancangan ini sistem harus mampu mengukur data posisi, kecepatan dan suhu.

- Rancang Bangun Wahana: wahana yaitu pelampung sebagai tempat bagi sistem elektronika sehingga sistem tersebut mampu mengukur dengan baik data posisi, kecepatan dan suhu.

- Rancang Bangun Sistem Penerima Data: data dikirimkan dengan menggunakan jaringan GSM berupa SMS (Short Message Services) dalam format tertentu. Sistem ini terdiri atas komputer, modem GSM dan program penerima.

2. Tahap Uji Coba Laboratorium dan Analisis Kerja Sistem

Sebelum sistem di uji coba di lapangan perlu dipastikan apakah sistem sudah sesuai dengan yang diharapkan oleh karena itu setelah proses rancang bangun sistem yang dibangun perlu dilakukan uji coba dilaboratorium. Ada beberapa parameter penting yang diperhatikan dalam uji coba ini yaitu ketelitian pengukuran posisi dan kecepatan GPS, ketelitian pengukuran suhu, daya apung, umur sumber energi $(a c c u)$, kinerja sistem penyimpanan serta sistem transmisi data.

\section{Tahap Uji Coba Lapangan}

Dilakukan pengukuran pasang surut sebelum pelepasan sampai hari terakhir dilepas. Drifter dilepaskan di 2 titik yang berbeda pada hari yang berbeda. Titik pertama di bagian tengah teluk dan titik kedua pada bagian pinggir teluk.

4. Tahap Analisis Data

Ada beberapa langkah yang dilakukan dalam proses analisis hasil yaitu:

- Analisis kerja

- Pembuatan track hasil

- Melihat pola gerak drifter dengan pola pasang surut teluk.

\subsection{Desain Wahana}

Wahana terdiri atas 2 bagian utama yaitu bola pelampung yang berisi perangkat elektronik dan parasut untuk mempertahankan posisi drifter dari pengaruh angin permukaan. Bola pelampung terbuat dari bola yang berbahan polypropelene, bola ini kemudian dimodifikasi sehingga dapat ditempatkan perangkat elektronik dengan baik didalamnya. Parasut menggunakan jaring padat dimana bagian ujung dan tengah ditambahkan lingkaran besi untuk memperkokoh dan mempertahankan bentuk parasut (Gambar 1).

\subsection{Desain Perangkat Elektronik}

Perangkat elektronik terdiri atas beberapa bagian utama yaitu catu daya yang diambil dari accu, mikrokontroler sebagai pusat pengendali dan pengolah data, modul GPS sebagai sensor posisi dan kecepatan, sensor suhu DS18B20, modul GSM sebagai transceiver data, dan modul data logger sebagai penyimpan dan backup data. Catudaya yang digunakan adalah accu 12 volt 7 Ampere Hour. 


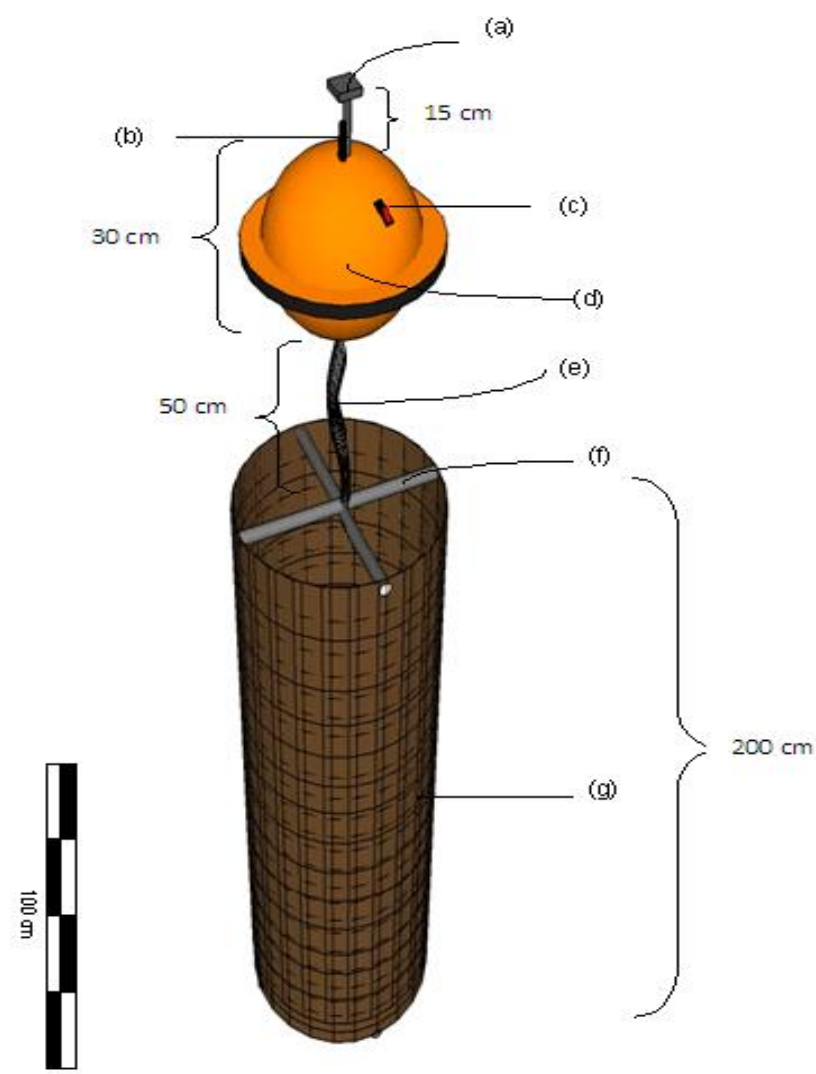

Keterangan:
(a) GPS
(b) Antena GSM
(e) Tali Penyambung pelampung dan parasut
(c) Kontrol Panel
(d) Pelampung Permukaan
(f) Besi Pembentuk parasut
(g) Parasut

\section{Gambar 1. Desain Drifter}

\subsection{Desain Perangkat Lunak Sistem}

Perangkat lunak terdiri atas perangkat lunak yang ditanamkan di dalam drifter dan perangkat lunak penerima data .

\section{1) Perangkat Lunak Drifter}

Perangkat lunak yang ditanamkan di dalam drifter terdiri atas beberapa fungsi utama yaitu mengakuisisi data yang dibutuhkan, menyimpan data dan mengirimkannya. Perangkat lunak ini dibangun menggunakan bahasa pemrogram BASCOM AVR yang merupakan bahasa pemrograman untuk mikrokontroler AVR. Perangkat lunak ini terdiri atas dua alur program yaitu alur program utama dan alur program interupsi (SMS konfigurasi). Pada saat dinyalakan mikrokontroler melakukan konfigurasi terutama untuk perangkat luar yang digunakan yaitu modem GSM, sensor suhu dan perangkat internal yaitu vektor interupsi RS232 yang digunakan untuk mendeteksi interupsi SMS masuk. Selama tidak ada interupsi mikrokontroler melakukan kegiatan rutin yaitu membaca GPS berupa posisi, jam dan tanggal serta kecepatan. Selanjutnya, membaca sensor suhu dan kemudian selama 5 menit membaca data posisi, kecepatan terakhir dan suhu. Data tersebut dirata-ratakan sebelum dikirim melalui modem GSM.

\section{2) Pembacaan GPS}

GPS yang digunakan (hampir semua GPS yang diproduksi) memiliki fasilitas komunikasi RS232 dan menggunakan standar komunikasi NMEA-0813. Perintah NMEA yang digunakan untuk pembacaan posisi dan kecepatan serta tanggal dan jam UTC yaitu \$GPRMC. Pembacaan oleh mikrokontroler dimulai dengan mendeteksi header data yaitu \$GPRMC kemudian urutan berikutnya adalah UTC Time, disela oleh satu karakter status 
kemudian pembacaan latitude di sela oleh satu karakter kemudian longitude disela oleh satu karakter lagi baru kemudian pembacaan kecepatan dan seterusnya berdasarkan urutan kalimat NMEA tersebut.

3) Perataan Data, Penyusunan Format dan Penyimpanan Data

Pengukuran dilakukan setiap 1 detik (waktu akuisisi GPS) dan untuk penghematan sumber daya pengiriman dilakukan setiap lima menit, oleh karena itu diperlukan perataan data suhu sehingga data yang terkirim adalah data hasil rata-rata sedangkan data yang tersimpan pada modul data logger adalah tetap data pengukuran setiap 1 detik. Posisi dan kecepatan dari GPS yang dikirim adalah posisi dan kecepatan terakhir.

\section{4) Pengiriman Data}

Data yang telah disusun berdasarkan format pengiriman kemudian dikirimkan melalui komunikasi RS232 dengan modem GSM melalui $A T$ Command. AT-Command yang digunakan adalah AT-Command pengiriman SMS yaitu AT+CMGS.

\section{5) Kendali dua Arah (Interupsi Rutin)}

Kendali dua arah yang dimaksud disini adalah merubah beberapa konfigurasi melalui jarak jauh menggunakan SMS berkode tertentu. Vektor interupsi RS232 dihidupkan sejak mikrokontroler bekerja, vektor interupsi berfungsi untuk mendeteksi penerimaan karakter dari modem. Jika ada karakter yang dikirimkan oleh modem ke mikrokontroler maka vektor interupsi tersebut akan melakukan rutin pengecekan berupa isi apakah karakter tersebut berupa AT-Command tanda SMS masuk, jika benar dilanjutkan dengan membaca SMS (AT+CMGR), kemudian kembali mencocokan nomor dan isi SMS apakah nomor pengirim adalah nomor yang diberikan hak pengendalian.

\section{6) Perangkat Lunak Penerima}

Perangkat lunak penerima berfungsi untuk menerima data yang dikirimkan oleh drifter. Perangkat lunak ini ditanamkan pada komputer yang memiliki modem GSM atau terhubung modem GSM sebagai perangkat keras penerima data.

Perangkat lunak ini dibangun dari bahasa pemrograman Borland Delphi 7 dan MySQL sebagai basisdata. Akses perangkat lunak ini ke modem GSM menggunakan komunikasi RS232 dengan API (Application Programming interface) AT-Command.

\subsection{Uji Coba Laboratorium}

Setelah melakukan desain dan pembuatan, instrumen kemudian di uji untuk mengetahui daya apung, lama operasi catudaya, akurasi data GPS, dan sensor suhu. Daya apung diuji di water tank Laboratorium Akustik Kelautan, ITK IPB kemudian diukur ketinggian badan wahana yang tenggelam. Lama operasi diujicoba dengan menyalakan instrument hingga instrumen tersebut tidak bekerja karena kehabisan catudaya, data GPS diuji dengan melakukan tracking kemudian melakukan plot hasil tracking tersebut di Google Earth apakah sesuai atau tidak dengan peta tersebut. Data suhu dibandingkan menggunakan termometer air raksa.

\subsection{Uji Coba Lapang}

Drifter diujicobakan di teluk Pelabuhan Ratu selama 2 hari, dilepas pada pagi hari kemudian sore diambil kembali. Sebelum pelepasan dilakukan terlebih dahulu dilihat tabel peramalan pasang surut dimana pada hari tersebut diharapkan bukan pasang perbani sehingga pola pergerakan pasang surut dapat terlihat cukup jelas.

\subsection{Analisis Data Lapang}

Data lapang yang telah diperoleh kemudian diolah untuk melihat kinerja dari yang telah dirancang. Data yang sudah tersusun dalam bentuk spreadsheet kemudian di plot menggunakan stick plot arus dengan pasang surut. Perhitungan jarak, arah dan kecepatan menggunakan hukum Pyhtagoras dan persamaan kecepatan konstan.

\section{HASIL DAN PEMBAHASAN}

\subsection{Rangkaian Elektronik}

Drifter yang dikembangkan berbasis mikrokontroler ATMega32 produksi ATMEL. Beberapa fungsi penting dari mikrokontroler ini yaitu melalui komunikasi serial menerima kalimat NMEA dari GPS, melakukan parsing terhadap NMEA \$GPRMC, sehingga 
didapatkan waktu UTC, posisi lintang dan bujur serta kecepatan dalam knot. Kemudian ATMega32 menggunakan fasilitas 1-wire yang dimiliki melakukan pembacaan terhadap sensor suhu DS18B20. Data yang telah dibaca tersebut kemudian disimpan kedalam bentuk file pada modul penyimpanan.

\section{1) Rangkaian Utama Mikrokontroler}

Rangkaian utama yaitu rangkaian minimum sehingga mikrokontroler dapat bekerja dan melakukan pemrograman. ATMega32 dalam rangkaian minimumnya cukup mudah yaitu dibangun dari mikrokontroler itu sendiri, kapasitor eksternal (X-TALL), kapasitor serta catudaya 5 Volt. Untuk melakukan pemrograman pada mikrokontroler ATMega32 juga sangat mudah yaitu hanya menghubungkannya dengan beberapa pin SPI (Serial Programming Interface).

2) Rangkaian Antarmuka GPS, Modem dan Sensor Suhu

Modem dan GPS menggunakan komunikasi serial RS232 untuk berkomunikasi dengan peralatan lain termasuk mikrokontroler, sehingga antarmuka cukup menggunakan fasilitas internal dari mikrokontroler ATMega32 baik hardware RS232 maupun RS232 secara software. Pada penelitian ini Hardware RS232 digunakan oleh Modem GSM dan RS232 digunakan oleh GPS. Modem yang digunakan menggunakan RS232 dengan level tegangan $\pm 12 \mathrm{~V}$ dan mikrokontroler adalah RS232 level TTL (5V) diperlukan IC Converter Max232. Sensor suhu menggunakan komunikasi 1-wire dalam komunikasinya yang juga tersedia di mikrokontroler.

\subsection{Rancang Bangun Perangkat Lunak}

Perangkat lunak dibangun menggunakan perangkat lunak BASCOM-AVR. Beberapa modul yang dihasilkan dalam penelitian ini yaitu:

1) Modul Pembaca GPS

Penelitian ini menggunakan NMEA \$GPRMC sebagai data yang akan diambil dari sekian banyak NMEA yang dikirimkan oleh satelit GPS. NMEA ini dikirimkan setiap 1 detik, sehingga dalam proses pembacaan data diperlukan proses pembacaan berulangulang (loop). Pembacaan sequensial dimulai dengan mendeteksi penanda
\$GPRMC apakah sudah diterima kemudian karakter selanjutnya dianggap sebagai waktu dan seterusnya, dimana delimiter format data \$GPRMC ini menggunakan karakter koma (“,”).

\section{2) Modul Data Logger}

Komunikasi MMC/SD card menggunakan pustaka MMC.bas yang disediakan oleh BASCOM-AVR dengan sedikit modifikasi dimana secara default BASCOM-AVR tidak mendukung ATMega32, serta clockrate yang digunakan. Perubahan ini dilakukan di file CONFIG_MMC.bas.

\section{3) Modul Program utama}

Dari beberapa sub program yang dibuat kemudian disatukan dalam satu kesatuan yang disebut program utama. Adapun alur program utama pada penelitian ini ditunjukkan pada Gambar 2. Pada saat pertama kali dinyalakan mikrokontroler akan melakukan konfigurasi seperti komunikasi modem, sensor suhu dan GPS dan vektor interupsi diaktifkan. Kemudian pembacaan GPS dilakukan yaitu berupa data posisi dalam lintang dan bujur dengan nilai kecepatan, tanggal dan jam, selanjutnya pembacaan sensor suhu dan menyimpannya di dalam data logger dan dikirimkan ke modem dalam bentuk perintah AT-Command SMS.

\subsection{Hasil Rancang Bangun}

Tampak Luar bagian dari instrumen tersebut yaitu GPS, Antena GSM, Kontrol Panel, Drogue, Sensor suhu. Adapun dimensi dari instrumen ini yaitu : panjang total pelampung $50 \mathrm{~cm}$ dengan diameter bola $30 \mathrm{~cm}$, dan berat total $10 \mathrm{Kg}$, diameter drogue $30 \mathrm{~cm}$ dengan panjang $200 \mathrm{~cm}$. Program penerima dibuat menggunakan perangkat lunak Delphi 7, program ini menerima SMS dalam bentuk $A T$ Command melalui port serial (USB) komputer.

\subsection{Hasil Uji coba Laboratorium}

Pengujian akurasi ketelitian posisi dilakukan dengan percobaan pada titik tetap yaitu drifter diletakan pada titik tetap selama 10 menit dan dilakukan pengukuran posisi secara terus-menerus (Tabel 1). Percobaan ini dilakukan pada tiga titik yang berbeda untuk melihat nilai kesalahan posisi pembacaan yang 
dihasilkan. Hasil ketiga titik tersebut memperlihatkan bahwa hasil pencatatan posisi memiliki nilai diameter maksimum $\pm 13.6 \mathrm{~m}$, Namun pada daerah terbuka kesalahan posisi hanya $\pm 4.5 \mathrm{~m}$.

Setelah seluruh rangkaian dibuat dan disatukan kemudian dilakukan pengujian, yaitu dengan membawa ke sekeliling kampus IPB Dramaga untuk melihat pengiriman, penerimaan dan ketelitian dari data yang dihasilkan. Hasil uji pertama ini kemudian di plot di Google Map untuk melihat ketepatan dari hasil pengukuran posisi GPS (Gambar 3).
Dari percobaan diperlihatkan bahwa GPS yang digunakan sudah cukup baik dalam memberikan posisi. Percobaan kedua kemudian dilakukan di water tank yaitu untuk menguji daya apung dan kedap air dari drifter yang telah dibuat. Hasil menunjukan bahwa bola pelampung terapung setengah bola $(15 \mathrm{~cm})$ dari keseluruhan bola. Hasil ini di anggap cukup untuk membuat drifter terapung dan sedikit dipengaruhi oleh angin permukaan.

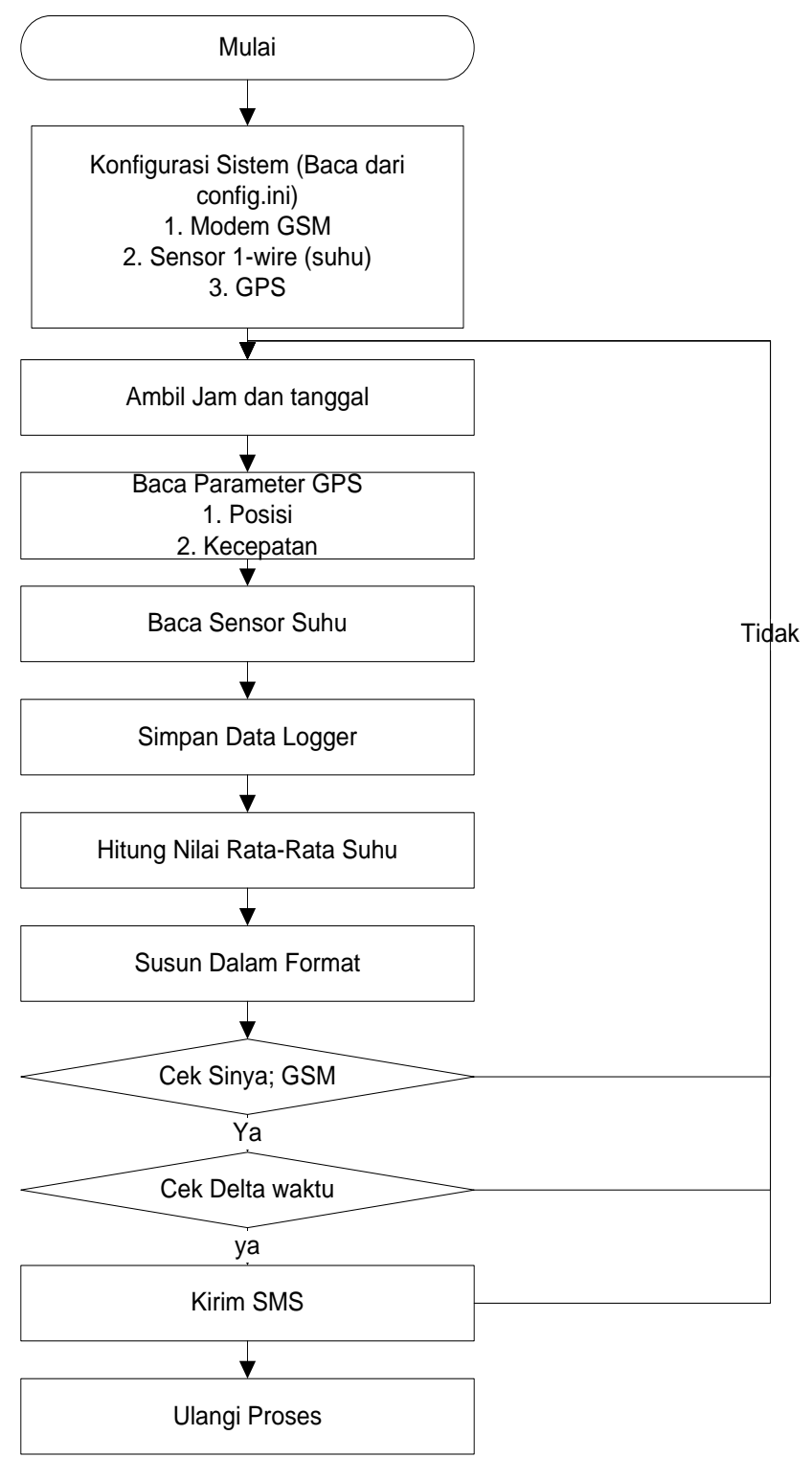

Gambar 2. Alur Program Utama 
Tabel 1. Hasil Ujicoba Penentuan Posisi pada titik tetap

\begin{tabular}{|c|c|c|c|}
\hline \multirow{2}{*}{ Titik } & & $\begin{array}{c}\text { Latitude } \\
\text { (ddmm.ssss) }\end{array}$ & $\begin{array}{c}\text { Longitude } \\
\text { (ddmm.ssss) }\end{array}$ \\
\hline \multirow{3}{*}{ I (Samping Gedung) } & Maksimum & 0633.5542 & 10643.4645 \\
\cline { 2 - 4 } & Minimum & 0633.5088 & 10643.4245 \\
\cline { 2 - 4 } & Range (Second) & $0.454^{-} \sim \mathbf{1 3 . 6 2} \mathbf{~ m}$ & $0.4^{-} \sim \mathbf{1 2} \mathbf{~ m}$ \\
\hline \multirow{3}{*}{ II (Tebuka) } & Maksimum & 0633.5515 & 10643.4296 \\
\cline { 2 - 4 } & Minimum & 0633.5427 & 10643.4281 \\
\cline { 2 - 4 } & Range (Second) & $0.088^{-} \sim \mathbf{2 . 6 4 4} \mathbf{~ m}$ & $0.15^{-} \sim \mathbf{4 . 5} \mathbf{~ m}$ \\
\hline \multirow{3}{*}{ III (Dibawah Pohon) } & Maksimum & 0633.4228 & 10643.4106 \\
\cline { 2 - 4 } & Minimum & 0633.4184 & 10643.4083 \\
\cline { 2 - 4 } & Range (Second) & $0.44^{-} \sim \mathbf{1 3 . 2} \mathbf{~ m}$ & $0.23^{-} \sim \mathbf{6 . 9} \mathbf{~ m}$ \\
\hline
\end{tabular}

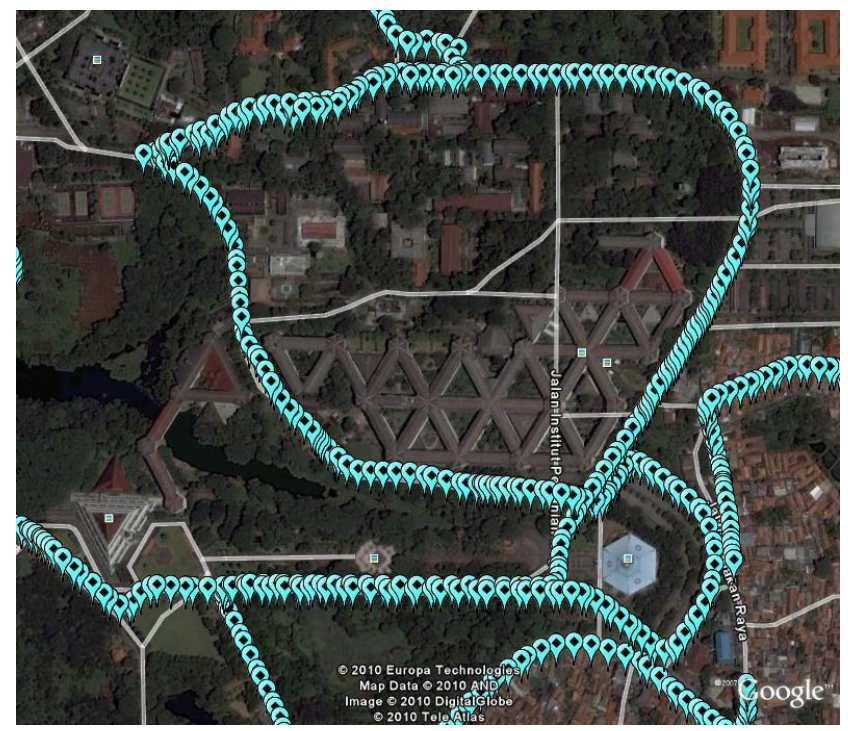

Gambar 3. Hasil Plot Data Uji Coba sekitar Kampus IPB Dramaga

Proses kalibrasi ini dilakukan dengan menngukur suhu air dingin yang dipanaskan secara pelan-pelan menggunakan thermometer sebagai alat standard an sensor suhu DS18B20 yang telah terbungkus. Kalibrasi Sensor suhu menghasilkan data dengan standar deviasi 0.42 , Rata-rata perbedaan suhu sebesar 1.582 derajat celcius dan maksimum beda sebesar 3.03 derajat celcius. Data percobaan tersebut kemudian dilakukan pencocokan (Gambar 4) sehingga didapatkan persamaan $\mathrm{Y}=1.004 * \mathrm{X}+1.432$ dengan $\mathrm{R}^{2}=0.996$, dimana $\mathrm{Y}$ adalah suhu terkoreksi dan $\mathrm{X}$ adalah suhu yang dikeluarkan oleh sensor DS18B20.

\subsection{Hasil Uji coba Lapang}

Ujicoba lapang dilakukan selama 2 hari. Penilaian kerja secara statistic dari
2 hari percobaan tersebut terlihat pada Tabel 2. Dari Table 2. tersebut terlihat lama operasi hari pertama dan kedua berbeda, hal ini dikarenakan trek hari kedua cenderung lurus dan hampir keluar teluk sehingga diputuskan untuk tidak dilanjutkan. Meskipun demikian terlihat bahwa data perubahan posisi hari kedua lebih banyak dibandingkan dengan hari pertama, hal ini disebabkan karena arus pada percobaan kedua lebih cepat dibandingkan dengan hari pertama sehingga perubahan posisi hari kedua lebih cepat dibandingkan hari pertama. Jumlah data terkirim juga berbeda hal ini kemungkinan disebabkan oleh perbedaan daerah menyebabkan penerimaan sinyal oleh modem GSM juga berbeda.

Data hasil pencatatan setiap detik kemudian dipisahkan hingga hanya data 
dengan posisi yang berbeda yang digunakan. Dari setiap data dengan posisi berbeda tersebut kemudian disamakan selang waktunya, selang waktu yang digunakan yaitu 10 menit. Data yang telah diolah tersebut kemudian diplot secara spasial untuk mengetahui pola gerak drifter (Gambar 4). Terlihat bahwa pola gerak drifter berbeda pada hari dan tempat yang berbeda. Hari pertama dilepas hampir pada bagian tengah teluk, pergerakan drifter cenderung menuju barat pada saat mulai surut, kemudian pada saat menuju pasang bergerak menuju utara. Hari kedua memperlihatkan bahwa gerak pada bagian teluk ini lurus menuju keluar teluk dengan kondisi surut, kemudian akan mulai berbelok pada siang hari.

Pada awal dan akhir setiap percobaan juga dilakukan pengukuran kecepatan dan arah arus secara manual. Hasil pengukuran manual kemudian diplot dan menjadi pembanding bagi data pengukuran drifter seperti terlihat pada Gambar 5a \& 6a. Terlihat bahwa hasil pengukuran manual dengan hasil pengukuran drifter memberikan hasil yang baik dimana perbedaan arah dan kecepatan kecil. Untuk melihat hubungan antara pola gerak drifter dengan pola pasang surut maka dibuatkan stick plot arus dan grafik pasang surut pada saat tersebut (Gambar 5b \& 6b).

\subsection{Data Suhu}

Rentang suhu pada percobaan hari pertama yaitu berkisar dari $28-30.1{ }^{\circ} \mathrm{C}$ dan $28.5 \quad-30.4{ }^{\circ} \mathrm{C}$ pada hari kedua (Gambar 7). pada awal percobaan terlihat suhu terjadi fluktuasi, hal ini disebabkan sensor masih menyesuaikan perubahan dari lingkungan udara ke air.

Baik pada hari pertama dan kedua terlihat bahwa respon time dari sensor suhu pada awal deploy membutuhkan waktu. Hal ini disebabkan karena sensor suhu tersebut dikemas dalam bahan alumunium, sehingga membutuhkan waktu untuk penyerapan suhu.

\subsection{Perbandingan Spesifikasi Drifter yang dihasilkan dengan Drifter ARGOS, ORBCOMM dan IRRIDIUM}

Adapun perbandingan dari drifter yang dihasilkan pada penelitian dengan drifter lainnya yaitu ARGOS, ORBCOMM dan IRRIDIUM sebagai teknologi drifter yang telah digunakan luas dan lama oleh para peneliti (Tabel 3). Komunikasi pada penelitian ini sudah dilakukan secara dua arah yaitu dengan adanya kendali dua.arah, Coverage area atau penggunaan drifter yang dirancang harus di daerah yang terdapat sinyal GSM sedangkan pada 3 perusahaan tersebut menggunakan komunikasi satelit. Drifter pada penelitian ini dapat digunakan pada daerah yang dekat dengan daratan seperti pesisir dan teluk yang memiliki BTS GSM. Data pada drifter yang dibuat menggunakan SMS sebagai media pengiriman data, jumlah data yang dapat dikirimkan sesuai dengan karakter maksimal yang dapat dikirimkan melalui SMS yaitu 160 karakter. Ketelitian pengukuran khusunya posisi sama yaitu $\pm 10 \mathrm{~m}$ sesuai dengan ketelitian Datasheet GPS, walaupun pada penelitian ini di dapatkan akurasi yaitu $\pm 4.5 \mathrm{~m})$. Identifikasi drifter dapat dilakukan melalui nomor GSM yang tertanam pada setiap drifter. Ini berbeda dengan aplikasi lain yang dibuat sendiri oleh perusahaan tersebut. Penggunaan daya pada penelitian ini masih jauh dari hemat seperti pada drifter yang dikeluarkan oleh 3 perusahaan tersebut dikarenakan efisiensi penggunaan komponen dan rangkaian. Pada drifter ini juga belum disertakan transmitter $\mathrm{HF}$ sehingga pengiriman data sangat tergantung dengan sinyal GSM ditempat percobaan. 


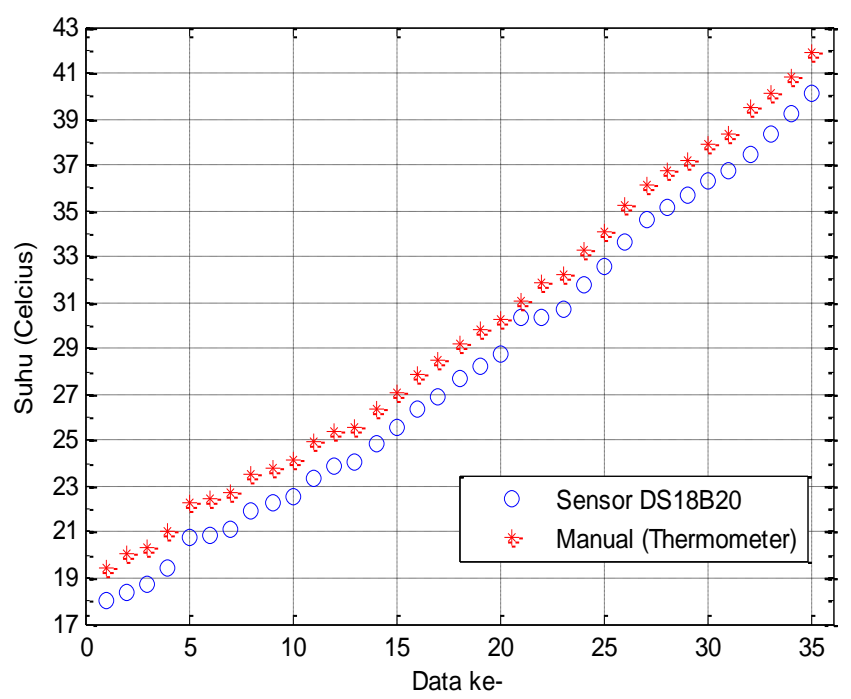

(a)

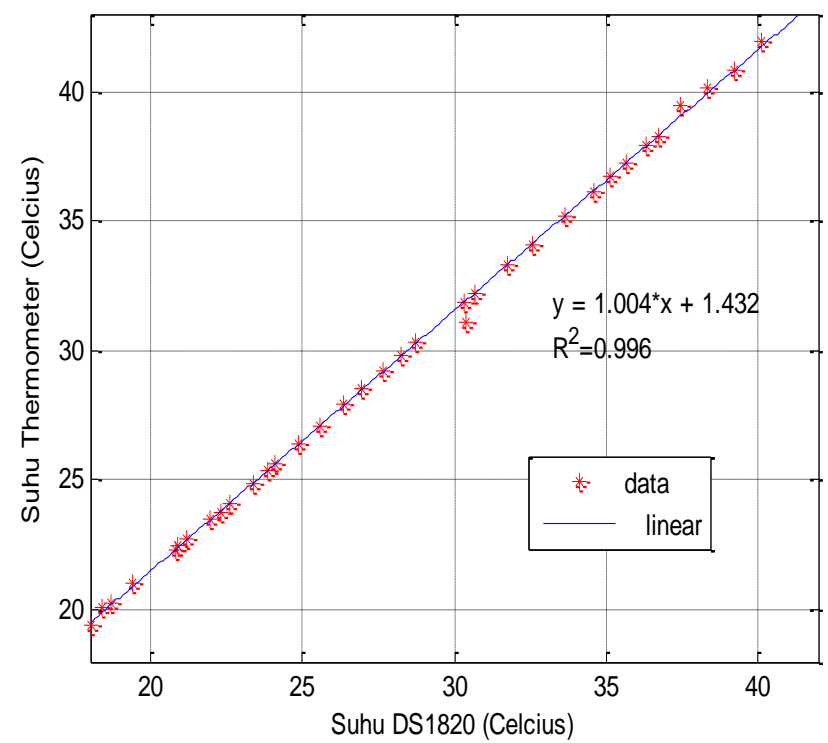

(b)

Gambar 4. (a) Plot Data Pengukuran, (b) Fit data Hasil Kedua Pengukuran

Tabel 2. Perbandingan Statistik Kerja Alat

\begin{tabular}{|l|l|l|}
\hline \multicolumn{1}{|c|}{ Jenis Parameter } & \multicolumn{1}{|c|}{ Hari Pertama } & \multicolumn{1}{c|}{ Hari Kedua } \\
\hline Lama Operasi (waktu) & 8 jam 20 menit & 6 jam 50 menit \\
\hline $\begin{array}{l}\text { Jumlah Data tersimpan } \\
\text { (buah) }\end{array}$ & $\begin{array}{l}18004\left(18028^{*}\right)=\mathbf{9 9 . 8 6 \%} \\
\text { sukses }\end{array}$ & $\begin{array}{l}14717\left(15435^{*}\right)=\mathbf{9 5 . 3 5} \% \\
\text { sukses }\end{array}$ \\
\hline $\begin{array}{l}\text { Jumlah Data Terkirim } \\
\text { (buah) }\end{array}$ & $72\left(84^{*}\right)=\mathbf{8 5 . 7 1 \%}$ sukses & $67\left(72^{*}\right)=\mathbf{9 3 . 0 5 \% \text { sukses }}$ \\
\hline Voltase Awal (volt) & 12.97 & 12.90 \\
\hline Voltase Akhir (volt) & $12.10(\mathbf{5 4 4} \mathbf{m W})$ & $12.25(\mathbf{5 4 1} \mathbf{~ m W})$ \\
\hline Jumlah Data Posisi Berbeda & $199\left(18004^{*}\right)=\mathbf{1 . 1} \%$ & $420\left(14717^{*}\right)=\mathbf{2 \%}$ \\
\hline
\end{tabular}

Keterangan : (*) adalah jumlah data yang seharusnya sesuai skenario yang direncanakan 


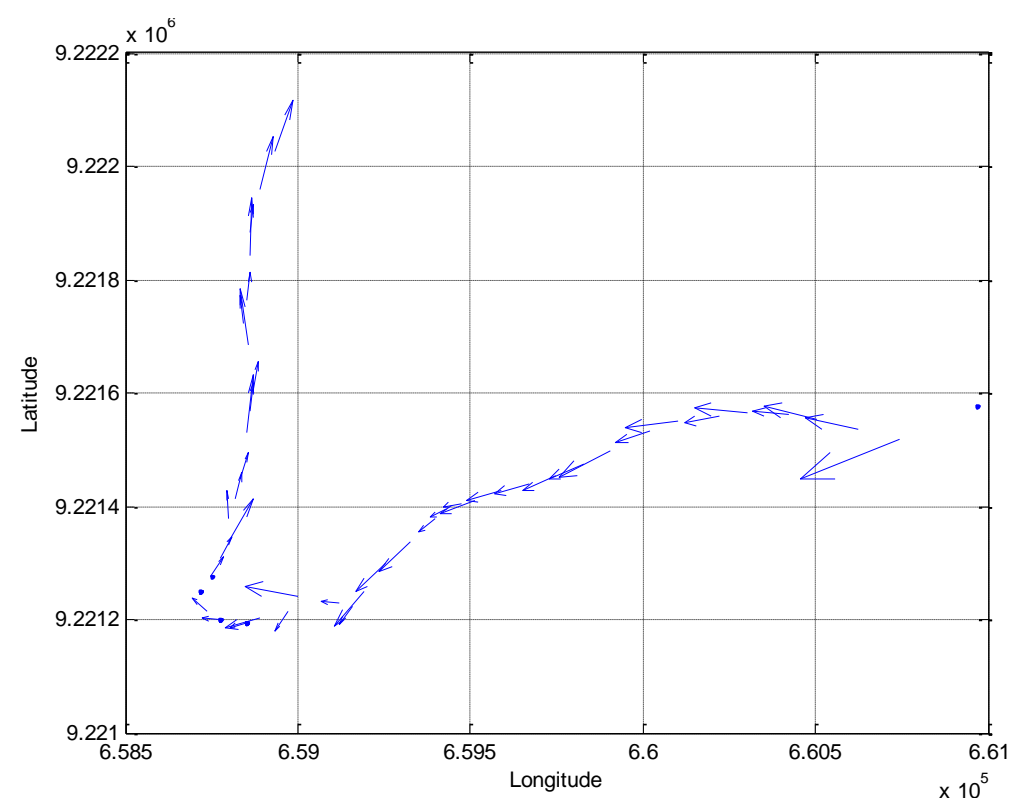

(a)

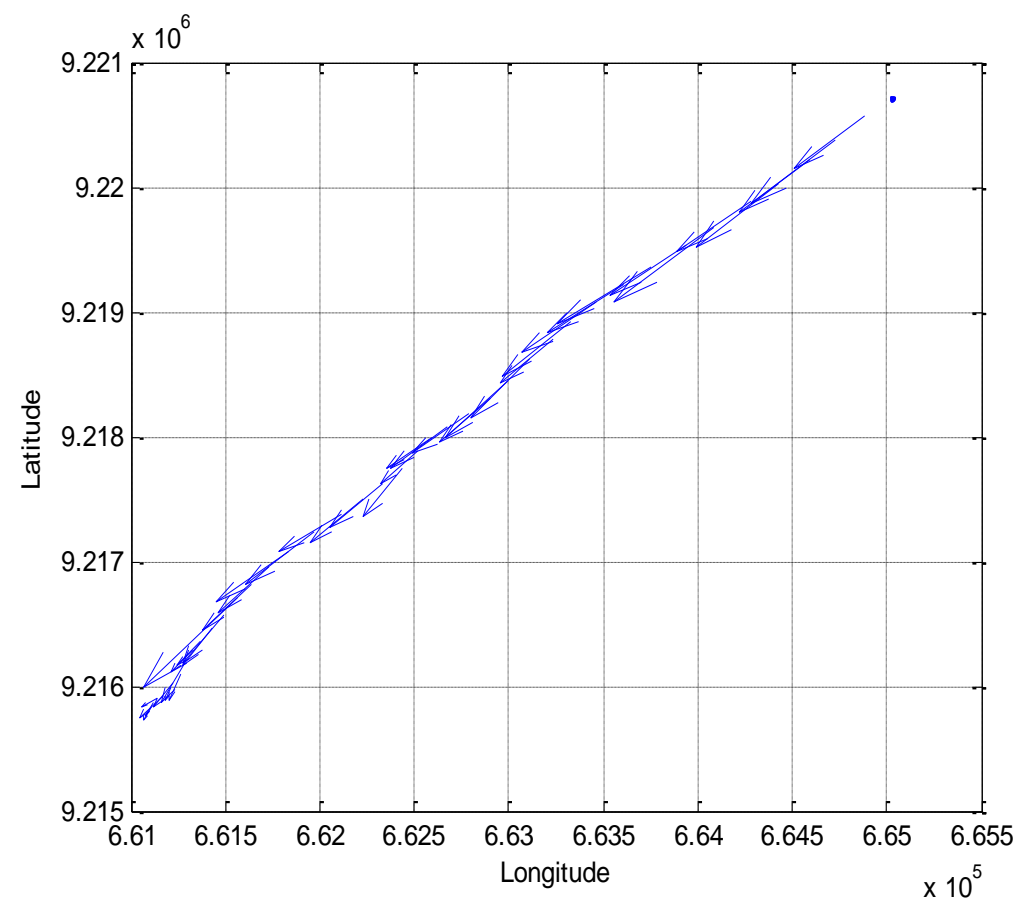

(b)

Gambar 4. Peta arah dan kecepatan arus pengukuran drifter (a) hari pertama, (b) hari kedua 

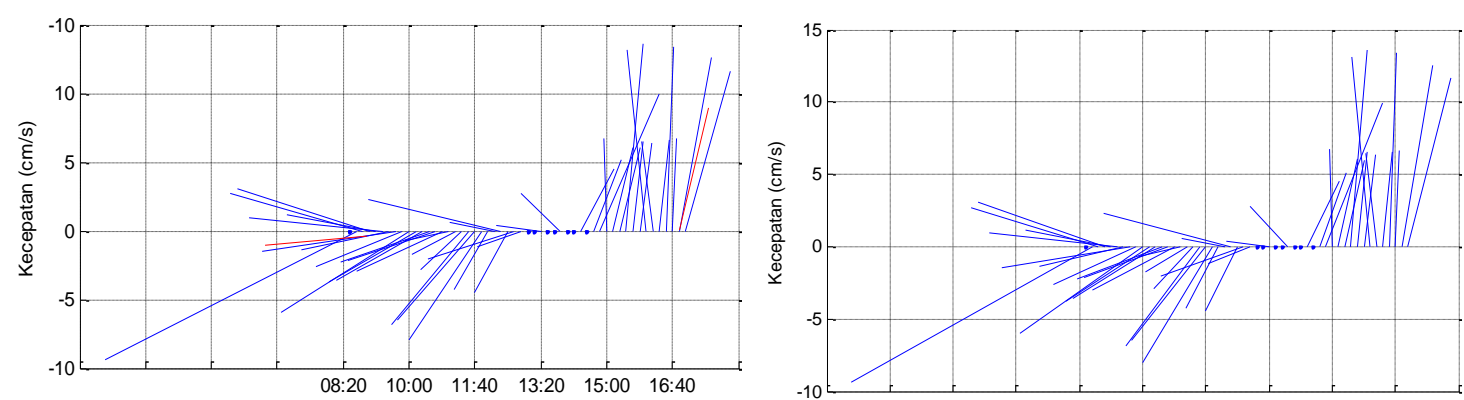

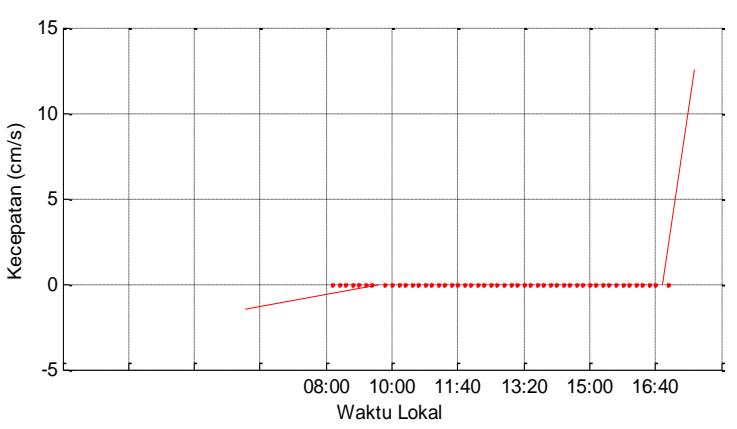

(a)

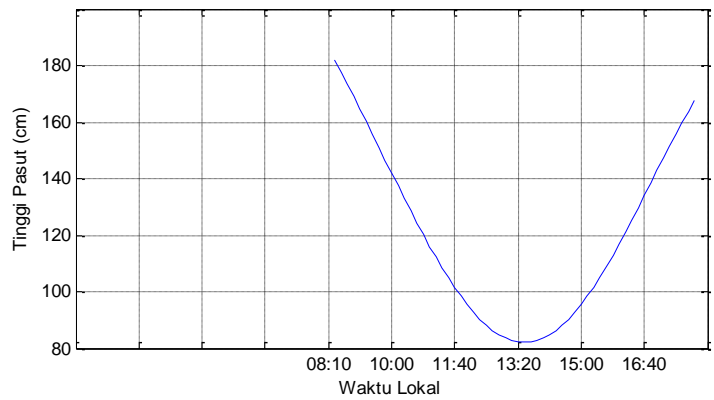

(b)

Gambar 5. (a) Stick plot pengukuran drifter hari pertama (atas) dan pengukuran manual (bawah), (b) Stick plot pengukuran drifter (atas) dan pasang surut (bawah)
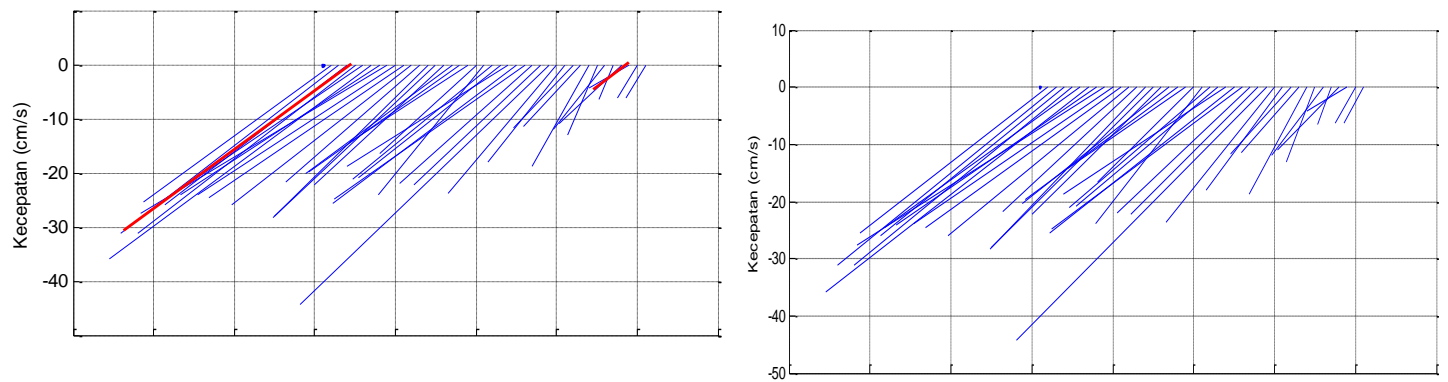

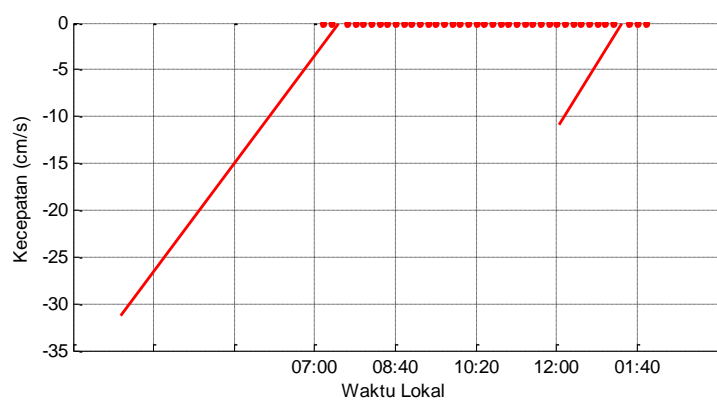

(a)

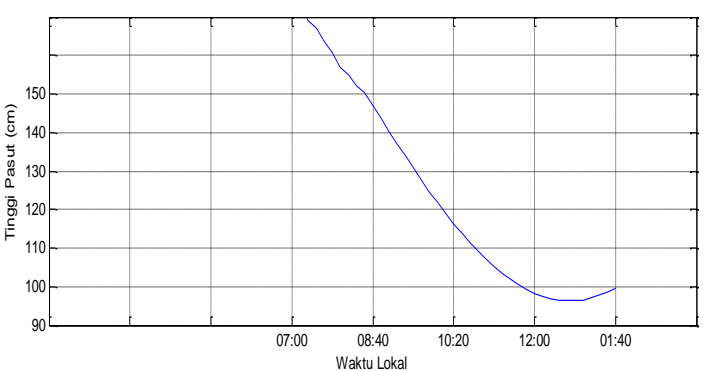

(b)

Gambar 6. (a) Stick plot pengukuran drifter hari pertama (atas) dan pengukuran manual (bawah), (b) Stick plot pengukuran drifter (atas) dan pasang surut (bawah) 

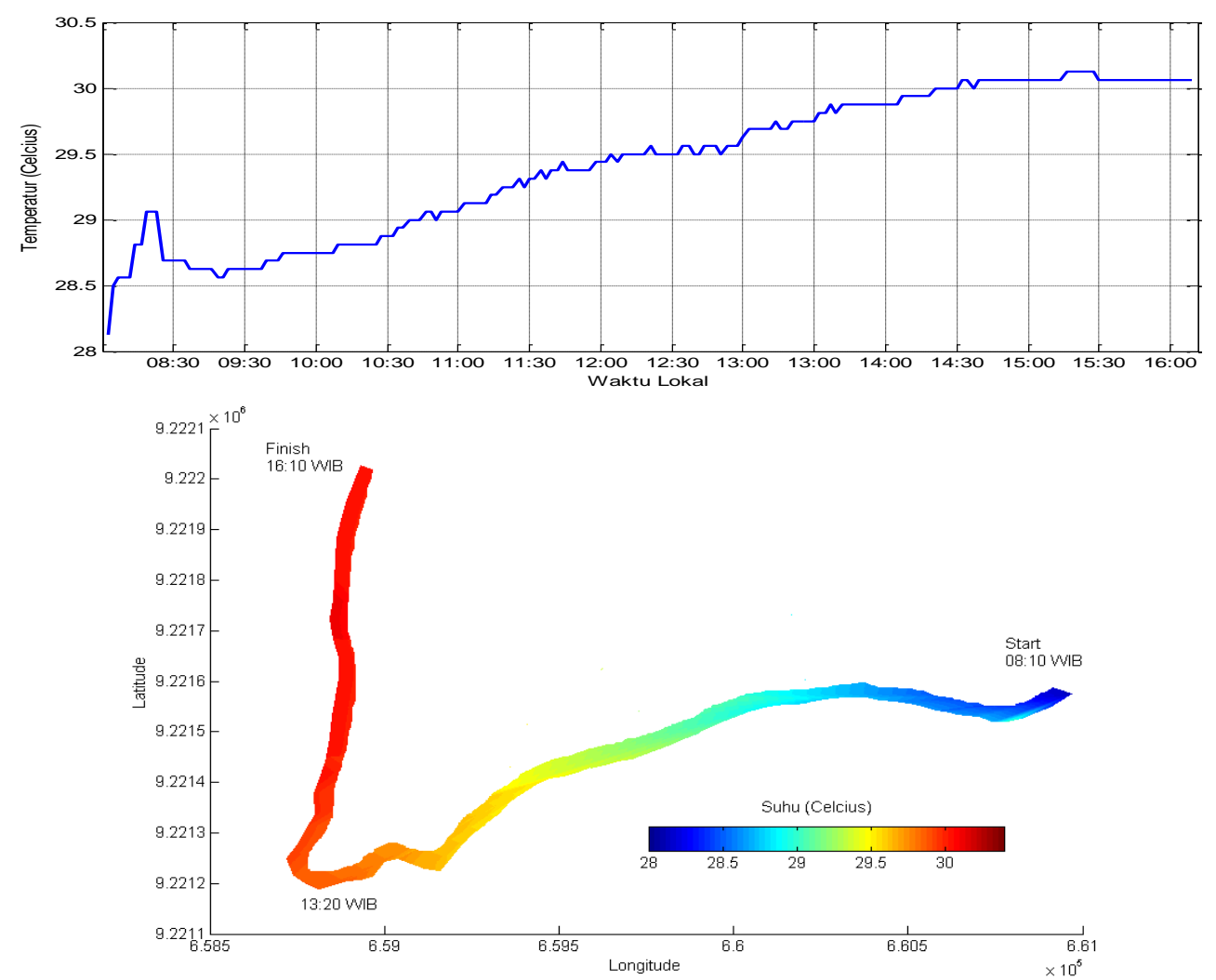

(a)
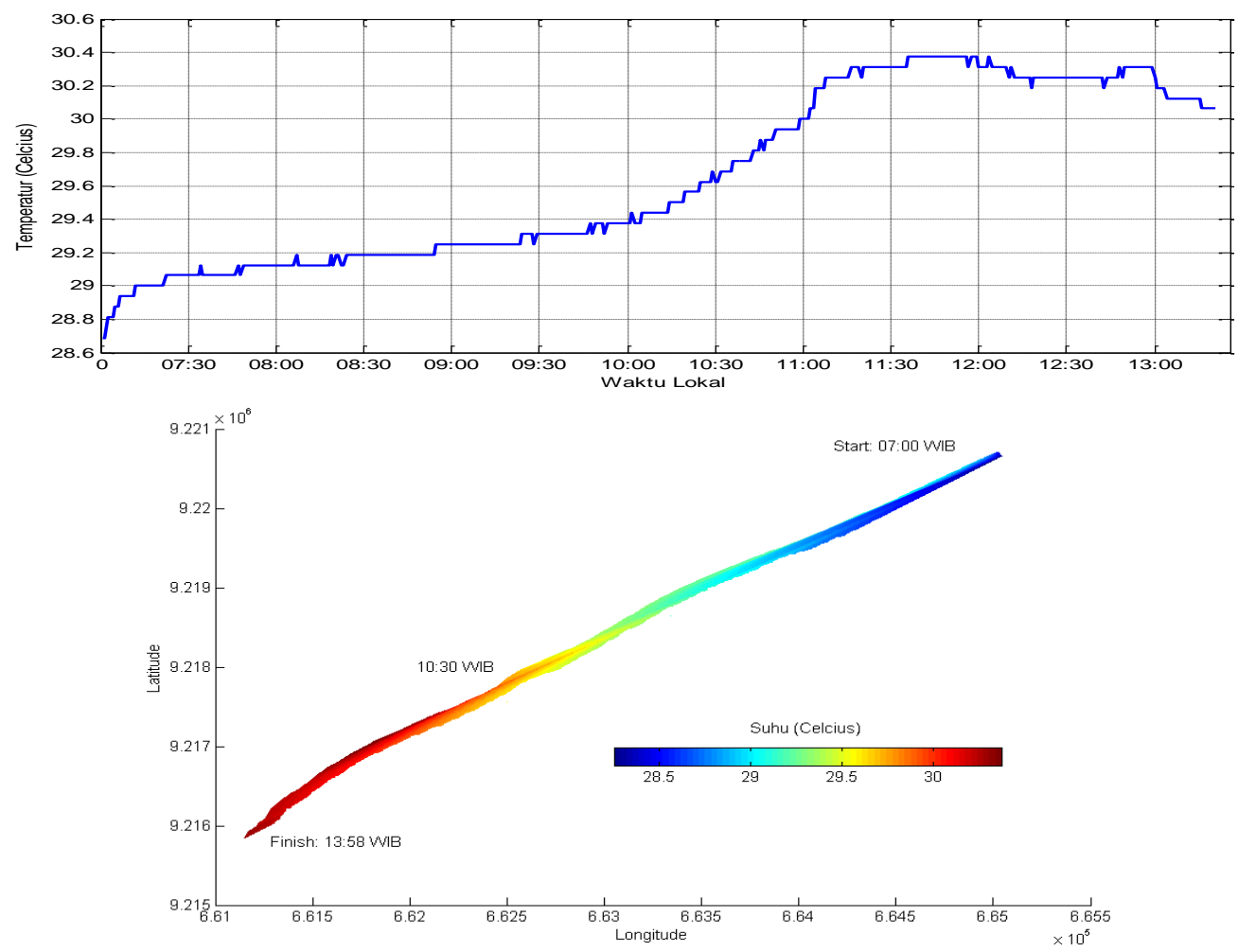

(b)

Gambar 8. (a) Suhu Hari pertama, (b) Suhu Hari Kedua 
Tabel 3. Perbandingan drifter yang dihasilkan dengan drifter ARGOS, ORBCOMM dan IRRIDIUM

\begin{tabular}{|c|c|c|c|c|}
\hline Perbandinagan & ARGOS & ORBCOMM & IRIDIUM & Penelitian ini \\
\hline $\begin{array}{l}\text { Communication } \\
\text { Method }\end{array}$ & $\begin{array}{l}\text { one way } \\
\text { (transmission) } \\
\text { only }\end{array}$ & two way & two way & Two way \\
\hline Coverage & $\begin{array}{l}\text { Global (number } \\
\text { of messages per } \\
\text { day depend on } \\
\text { latitude) }\end{array}$ & $\begin{array}{l}\text { between }+60 \text { and }- \\
60 \text { deg latitude }\end{array}$ & Global & GSM Signal \\
\hline $\begin{array}{l}\text { Remote System } \\
\text { control (change } \\
\text { message rate and } \\
\text { message type) }\end{array}$ & no & yes & yes & yes \\
\hline $\begin{array}{l}\text { Max. Number of bytes } \\
\text { in message }\end{array}$ & $\begin{array}{l}32 \text { bytes ( } 20 \text { bit } \\
\text { ID) } 31 \text { bytes ( } 28 \\
\text { bit ID) }\end{array}$ & 512 bytes & 100 Kbytes & 160 charakter \\
\hline Position & $\begin{array}{l}\text { by sattellite }( \pm \\
300 \mathrm{~m})\end{array}$ & by GPS $( \pm 10 \mathrm{~m})$ & by GPS $( \pm 10 \mathrm{~m})$ & $\begin{array}{c}\text { By GPS }(( \pm 10 \\
m)\end{array}$ \\
\hline Position drift alarm & $\begin{array}{l}\text { As option by } \\
\text { Argis or using } \\
\text { W@ves } 21 \text { or } \\
\text { seasaw software }\end{array}$ & $\begin{array}{l}\text { As option by Argis } \\
\text { or using W@ves } 21 \\
\text { or seasaw } \\
\text { software }\end{array}$ & $\begin{array}{l}\text { As option by Argis } \\
\text { or using W@ves } 21 \\
\text { or seasaw software }\end{array}$ & - \\
\hline Transmiter ID & $\begin{array}{l}\text { to be obtained } \\
\text { from CLS to } \\
\text { setup buoy } \\
\text { system }\end{array}$ & $\begin{array}{l}\text { to be specified as } \\
\text { part of } \\
\text { provisioning by an } \\
\text { orbcomm service } \\
\text { provider }\end{array}$ & $\begin{array}{l}\text { phonenymber of } \\
\text { the iridium } \\
\text { subscription }\end{array}$ & GSM Number \\
\hline $\begin{array}{l}\text { Typical Power } \\
\text { consumption }\end{array}$ & $\begin{array}{l}\text { ca } 70 \mathrm{~mW} \text { ca } 40 \\
\mathrm{~mW}\end{array}$ & $\begin{array}{l}\text { ca } 100 \mathrm{~mW} \mathrm{ca} \\
200 \mathrm{~mW}\end{array}$ & ca $74 \mathrm{~mW}$ & $\pm 544 \mathrm{~mW}$ \\
\hline $\begin{array}{l}\text { Combintaion with } \\
\text { local HF transmitter }\end{array}$ & yes & yes & 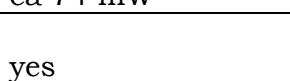 & no \\
\hline $\begin{array}{l}\text { Disable option and/or } \\
\text { activity }\end{array}$ & yes & yes & yes & yes \\
\hline
\end{tabular}

\section{KESIMPULAN DAN SARAN}

\subsection{Kesimpulan}

Ada 3 bagian utama dari drifter yang dibangun yaitu sistem elektronika, perangkat lunak dan wahana. Sistem elektronika dibangun dari mikrokontroler ATMega32, penyimpanan SD/MMC card, transmisi menggunakan modem GSM, GPS sebagai sensor posisi dan kecepatan, DALLAS DS18B20 sebagai sensor suhu. Perangkat lunak dibagi menjadi 2 bagian yaitu perangkat lunak yang ditanamkan di wahana dan perangkat lunak pada pengendali di darat menggunakan komputer. Wahana dibagi menjadi 2 bagian utama yaitu bola pelampung sebagai tempat bagian elektronika buoy dan parasut yang berfungsi untuk mempertahankan posisi drifter dari pengaruh angin permukaan.

GPS yang digunakan memiliki ketelitian $10 \mathrm{~m}$, oleh karena itu penentuan posisi memerlukan selang waktu tertentu, selang waktu ini sangat bergantung dari kecepatan arus permukaan di daerah tersebut. Semakin cepat semakin kecil selang waktu yang bisa diimplementasikan. Pada saat percobaan dilapangan data yang dihasilkan oleh drifter mampu memberikan gambaran bahwa arus permukaan di Pelabuahan Ratu diperngaruhi oleh pasang surut daerah tersebut.

\subsection{Saran}

Desain, dan rancang bangun yang telah dihasilkan diharapkan terus dikembangkan sehingga mampu mengatasi kelemahan-kelemahan pada penelitian ini, seperti ketelitian GPS yang kemudian berpengaruh terhadap interval pengukuran. Desain wahana yang lebih baik sehingga memudahkan pengoperasian dan terutama tidak rawan pencurian. 


\section{DAFTAR PUSTAKA}

Defant, A. 1958. Ebb And Flow. The Tides of Earth, Air, and Water. The University of Michigan Press. Michigan.

Griffa, 2007. Lagrangian Analysis and Prediction of Coastal an Ocean Dynamics. Cambridge University Press, New York.

Lumpkin, 2005. Evaluating the decomposition of tropical Atlantic observations. Journal of Atmospheric and Oceanic Technology, submitted.
Niiler, 2001. Ocean Circulation and Climate, International Geophysics Series, vol. 77. Academic Press, New York, pp. 193-204.

Pazan, 2000, Recovery of near-surface velocity from undrogued, Journal of Atmospheric and Oceanic Technology 18(2000), pp. 476-489.

Purba, F. 1995. Model dan Simulasi Pola Arus Perairan Teluk Pelabuhan Ratu dengan Metode Beda Hingga Eksplisit. Skripsi Fakultas Perikanan dan Ilmu Kelautan, Institut Pertanian Bogor. 